\title{
蚊成虫の行動に及ぼす殺虫剤の 影響に関する室内試験
}

\author{
栗原毅海野登久子 \\ 帝京大学医学部（尔173 東京都板橋区加賀）
}

(受領：1986年 4 月 18 日)

The effects of insecticides on the behaviour of female mosquitoes under laboratory conditions

Takeshi KURIHARA and Tokuko UMINO

Teikyo University School of Medicine, Kaga, Itabashi, Tokyo 173, Japan

Key words: insecticide-treated net, behavioural responses, deterrent effect, irritability, pyrethroid.

屋内壁面などに散布された 殺虫剤が，致死作用以外 に，蚊成虫に特異な反応・行動を起こさせるひきがると なることは，すでに DDT を多用した時代に知られて Wた (Mattingly, 1962; Muirhead-Thomson, 1960). 近年ピレスロイドが使用されるにさいし，やはり似たよ うな行動を誘発することが注目されている.たとえば， フタレスリン散布後, 対象蚊種が散布屋内に侵入せず, 侵入吸血してもすぐ外一逃避してしまう（Smith and Chabeda, 1969).フェノトリンの試験では, 飛来蚊数の 減少と吸血率の低下をみた（Kurihara et al., 1986). このような結果は, 殺虫効果や防疫という目的を損うこ とがないのか否か，関心を寄せざるを得ない．

従来, 殺虫片の評価法としてのバイオアッセイは, 致 死効力測定が主体であった。しかし上述のような状況か ら，薬凨によって注蚊が示す反応をも把握する室内試験 の必要性が高まったといえよう，乞の反応は，処理家屋 内への侵入, その中での吸血, 吸血後の休止や脱出など 多方面にわたり，本来とっていた行動を逸脱させてい る. 加えて殺虫剤ごとに，また供試蚊種により反応の強 弱が異なることも充分予測しうる. そしてこれら反応を 簡易に検討寸る試験法の開発が求められる.

筆者らは，薬剤を浸漬した目のあらいナイロン漁網を 用いたケージテストが，上述のような反応を観察する のに適当と思利れることを先比報告した（栗原ら，1985 a).その折の成績に基づき，一部改良を加えて試験を進 めたところ，反応検出の目的にかなうものと判断され た. 以下はその装置と, 試験に供した 2 薬剤 4 蚊種でえ られた成績である.

\section{材料と方法}

\section{装置}

前報（栗原ら，1985 a）と同じ，あい対する二面に口 径 $15 \mathrm{~cm}$ の開孔部をもつ $30 \mathrm{~cm}$ 角のステンレス製ケー ジ 2 コを, 各一方の開孔部を密接させて主装置とした (Fig. 1).ケージの一方には金網で固定したマウスを入 れてベイト・ケージ（以下Bケージと称す）とし，他方 は原則として供試蚊を放つリリース・ケージ（R ケー ジ）とした．両ケージとも， $2 \%$ 砂糖水 $5 \mathrm{~g}$ を綿にしみ こませて供されている，殺虫剤を浸漬したナイロン製漁 網は, 線径 $0.4 \mathrm{~mm}$, 目の大きさ $10 \times 10 \mathrm{~mm}, 1 \mathrm{~m}^{2}$ 亦 たり重量 $25.6 \mathrm{~g}$ のものである.

今回供した殺縗はフェノトリンまたはフェニトロチ オンいずれも，5\%乳刋で, 水で希釈して各濃度 $80 \mathrm{ml}$ を用意しここれに上述の網 $1 \mathrm{~m}^{2}$ を浸漬させた. 自然乾 燥の後, $25 \times 20 \mathrm{~cm}$ の大きさに裁ち，1力月室温に放置 してから使用した。 こうして殺虫郕が $1 \mathrm{~m}^{2}$ あたり， $0.0025,0.01,0.04,0.16,0.64,1.28,2.56$ または $5.12 \mathrm{~g}$ 付着しているように準備した. 同浱度の網を 1 


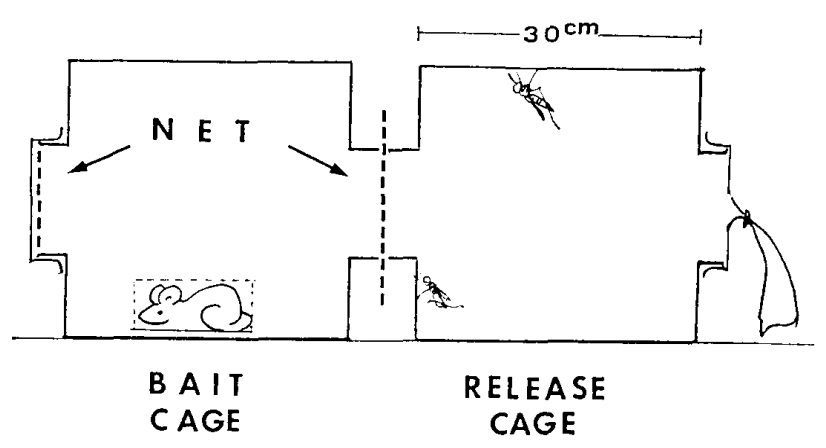

Fig. 1 Apparatus for determining the effect of insecticide. The wide-mesh net was impregnated with the candidate insecticide at different doses.

枚ずつBケージの二面の開孔部にたるみなく張る．この うち両ケージの中間に位唄する網は, 網目を蚊が自由に 通過できる，他方の網は外側をポリエチレン・シートで おおっている。

\section{供 試 蚊}

累代飼育中の次の 4 群である.

Anopheles stephensi (yoelii コロニー).

ヒトスジシマカ Aedes albopictus (上尾コロニー).

アカイエカ Culex pipiens pallens (富山コロニー).

ネッタイイエカ Cx. quinquefasciatus(沖繩コロニー).

おの㧍のの供試 2 薬剂処理網に対する感受性は, 前報 の方法により測定され，Table 1 の結果をえている（栗 原ら，1985 a,b (既報)).アカイエカがフェニトロチオ ン抵抗性とみられる。

\section{方 法}

羽化後 5 日の未吸血雌 25 匹前後を一群として，午後 3 時に放し， $24 \sim 26{ }^{\circ} \mathrm{C}, 60 \sim 70 \% \mathrm{R}$. H., 自然光照明 のもとに放置し，翌朝 10 時に全供試蚊を吸虫管で回収 した. 回収蚊は, 生死, 吸血の有無と回収場所（B・R 各ケージの別) を記録した. 各組合せ $2 \sim 4$ 回繰返し試 験した。実験 1 はRケージに蚊を放し，この場合「侵入 蚊」と称するのは，回収蚊の中でBケージに一度は侵入 したと判断された蚊，才なわち全吸血蚊とBケージ内で 回収した未吸血蚊数の和を指している，侵入率はこの和

Table 1 Observed values of LT50 (in $\mathrm{min}$ ) of unfed females exposed by tarsal contact to the wide-mesh net impregnated insecticides at a dosage of $0.16 \mathrm{~g} / \mathrm{m}^{2}$.

\begin{tabular}{lcc}
\hline & Phenothrin & Fenitrothion \\
\hline An. stephensi & 10 & 60 \\
Ae. albopictus & 40 & 110 \\
Cx. pipiens pallens & 200 & 200 \\
Cx. quinquefasciatus & 10 & 70 \\
\hline
\end{tabular}

の全供試蚊との比率である， R ケージから未吸血で回 収された蚊は含まない，そして実験 2 では蚊を Rケージ ではなく，Bケージのマウスの傍に放した試験である.

\section{成 績}

\section{実 験 1}

Table 2 に各薬剤濃度別，蚊種別に，供試蚊の致死率 を示した。フェノトリンに対しては，施用量の増加に伴 い致死率が高まる傾向を示す。しかし，4 種の供試蚊い ずれも感受性が低くはないのに，高濃度でも $100 \%$ 致死 率は得られなかった.フェニトロチオンに対しては，抵 抗性のアカイエカの場合だけは，致死率が無処理区と大 差がなかった.

Fig. 2 に示すように，無処理の網が張られている場 合は，いずれの蚊も侵入率，吸血率ともに比較的高率で あった。しかし，フェノトリン処理では，侵入率が高施 用量ほど漸减，または無処理よりも著しく低減した，し かし逆に「侵入を避けてRケージで生存していた蚊（侵 入を避けて Rケージで生存していた蚊 (侵入忌避蚊)」 の比率が，とくに 0.04 0.16 g/ $\mathrm{m}^{2}$ 前後の濃度では, 無 処理よりも高い率を示した，実際，An. stephensi は R ケージ内でも網から最も遠い面に，生存蚊が多数集まっ て避けている特異な現象が観察された。侵入忌避蚊の比 率は濃度が高いとまた低下し，無処理と同程度にまで下 がる.ただしアカイエカは例外で，この比率が無処理よ り特に高い，という濃度段階を認めることがなかった。 フェニトロチオン処理の場合，侵入率は施用量の大小に よる変動が少ない. 侵入忌避蚊の比率も上述のフェノト リンにみられるような変動がなく, アカイエカ以外は極 度に低下してしまった。

フェノトリンでは，高濃度ほど吸血率が低下した。ア カイエカでは $1.28 \mathrm{~g} / \mathrm{m}^{2}$, ネッタイイエカでは $0.64 \mathrm{~g} / \mathrm{m}^{2}$ でゼロになった．フェニトロチオンでも吸血率の低下は みるが，フェノトリンほどには極端に低下しない，たと えばヒトスジシマカの $5.12 \mathrm{~g} / \mathrm{m}^{2}$ での吸血率は, 無処理 での吸血率との間に有意な差がない。

しかし吸血率の高低は，侵入率の大小にも影響され る.そこで網のバリヤーを一度は通過した「侵入蚊数」 に対する吸血の比率を比較した（Fig. 3).フェノトリ ン低濃度の処理の場合, 侵入蚊の中の吸血蚊率は高い. アカイエカ以外の 3 種は, 無処理区よりも高い率すら示 した. しかしヒトスジシマカ以外は $0.04 \sim 0.64 \mathrm{~g} / \mathrm{m}^{2}$ で 急に吸血蚊率が低下してしまう。そして，侵入しながら も，吸血を避けて生存している個体が増える，その比率 は，ヒトスジシマカ以外の 3 種では，無処理区よりもは るかに高率となったが，より高濃度ではまた低率化し 
Table 2 Over-all mortalities(\%) of mosquitoes in two cages.

\begin{tabular}{|c|c|c|c|c|c|}
\hline Insecticide & $\begin{array}{l}\text { Dosage } \\
\left(\mathrm{g} / \mathrm{m}^{2}\right)\end{array}$ & $\begin{array}{c}\text { An. } \\
\text { stephensi }\end{array}$ & $\begin{array}{c}\text { Ae. } \\
\text { albopictus }\end{array}$ & $\begin{array}{l}\text { Cx.p. } \\
\text { pallens }\end{array}$ & $\begin{array}{c}C x . \\
\text { quinquefasciatus }\end{array}$ \\
\hline \multirow[t]{8}{*}{ Phenothrin } & 0.0025 & 27.2 & 8.3 & 5.8 & - \\
\hline & 0.01 & 27.2 & 3.1 & 8.8 & - \\
\hline & 0.04 & 42.2 & 5.7 & 7.9 & 1.8 \\
\hline & 0.16 & 64.7 & 21.0 & 4.8 & 24.0 \\
\hline & 0.64 & 76.9 & 46.5 & 15.4 & 27.7 \\
\hline & 1.28 & 86.7 & 68.5 & 25.9 & 45.2 \\
\hline & 2.56 & 83.6 & 71.7 & 42.6 & 70.0 \\
\hline & 5.12 & - & 75.0 & 64.6 & 75.0 \\
\hline \multirow[t]{8}{*}{ Fenitrothion } & 0.0025 & 31.3 & 5.7 & 2.5 & - \\
\hline & 0.01 & 50.0 & 9.0 & 5.4 & - \\
\hline & 0.04 & 97.3 & 38.8 & 7.8 & 56.6 \\
\hline & 0.16 & 100 & 77.7 & 6.4 & 56.3 \\
\hline & 0.64 & 96.0 & 75.8 & 12.5 & 88.8 \\
\hline & 1.28 & 100 & 90.6 & 10.2 & 100 \\
\hline & 2.56 & 100 & 86.6 & 7.5 & 100 \\
\hline & 5.12 & - & 96.4 & 7.0 & 94.3 \\
\hline Untreated & & 11.5 & 8.9 & 6.8 & 1.6 \\
\hline
\end{tabular}

The insecticide impregnated net was interposed between two cages, and the mosquitoes were introduced into the release-cage.
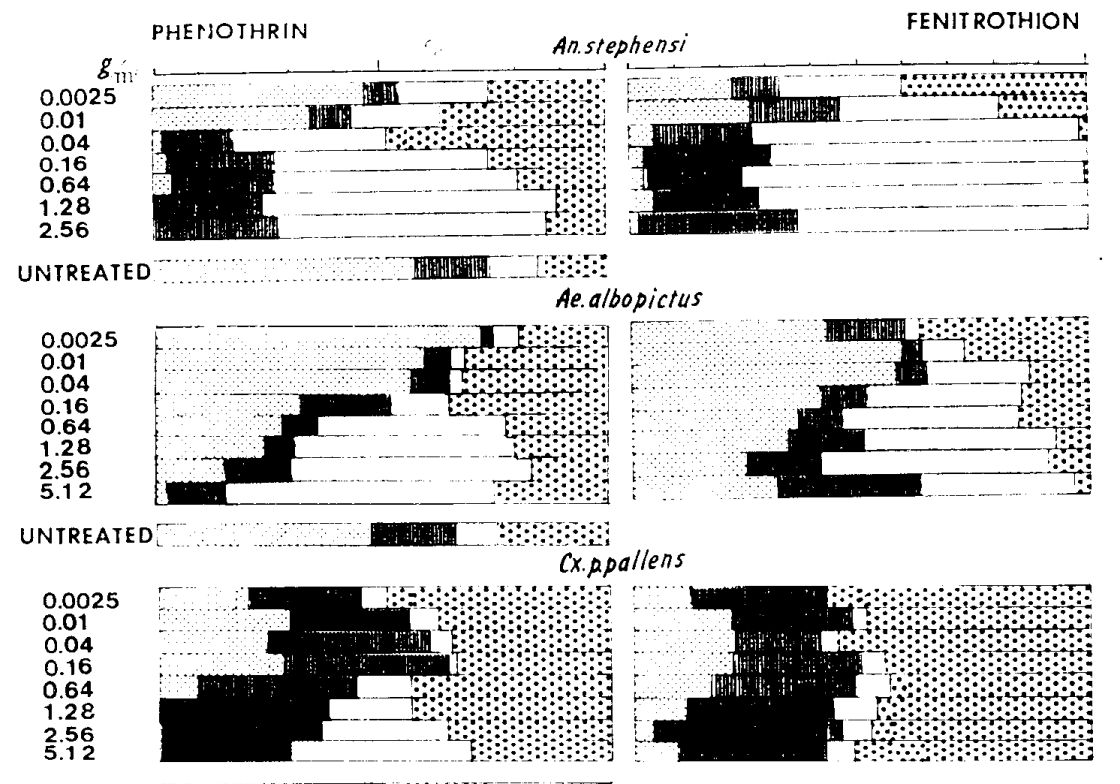

UNTREATED

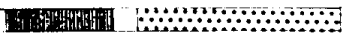

Cx.quinquefasciatus

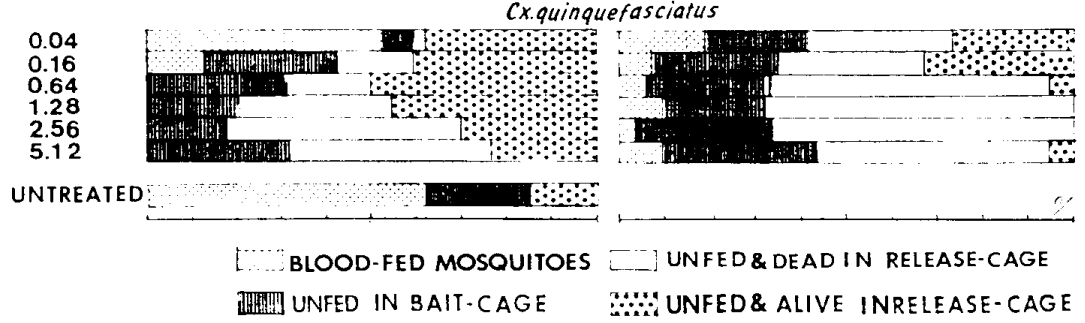

Fig. 2 Responses to insecticides in terms of entry (=blood-fed mosquitoes + unfed mosquitoes in bait-cage) and feeding of four species of mosquitoes. 


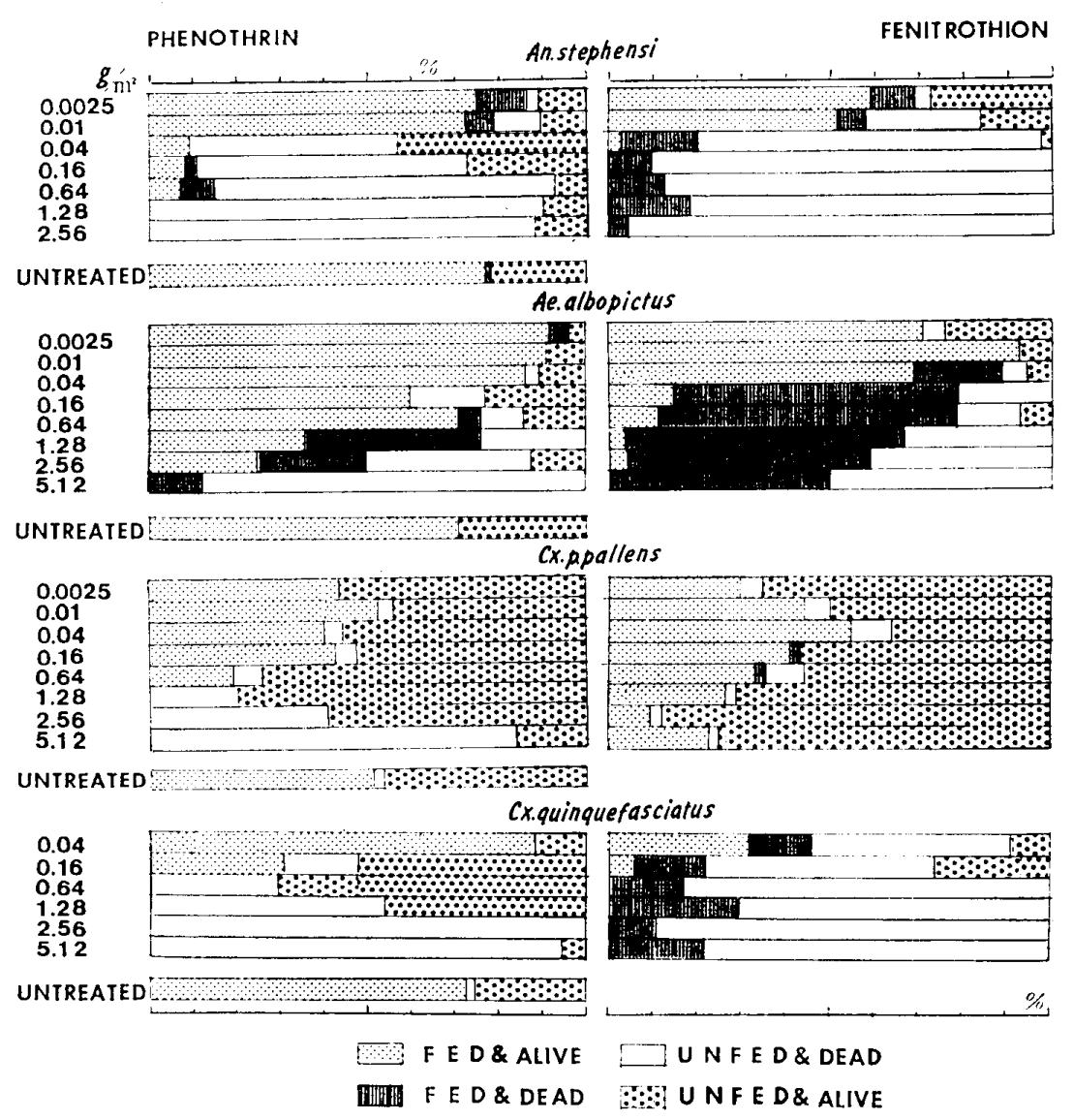

Fig. 3 Responses to insecticides in terms of feeding and feeding deterrency of mosquitoes entered in the bait-cage.

た. ヒトスジシマカの吸血率も高濃度で低下はしたが, 生存未吸血蚊の比率は無処理ほどには高くはならなかっ た.

フェニトロチオン処理での吸血蚊比率は，フェノトリ ンよりも概して高い.しかし吸血した蚊の致死率も高い. 抵抗性のアカイエカは, 致死率は低かったが, 侵入して も未吸血のまま生存している比率が著しく高まった．と くに高濃度では顕著であった。このような現象は他の 3 種には認められなかった。

吸血した蚊の回收場所を比較すると（Fig. 4)，無処 理の場合，吸血蚊の過半数は吸血をした B ケージ内に生 存して回收された。 その比率は An. stephensi では全 吸血蚊数の $86.2 \%$ ，ヒトスジシマカ $81.1 \%$ ，アカイエ カ $54.1 \%$ ，ネッタイイエカ $62.1 \%$ に相当した.この值 汁薬剤処理網を供することにより低下し，吸血後Rケー ジへ戻る吸血蚊の比率が高まった．フェノトリン処理で は An. stephensi とネッタイイエカ（本種は吸血例数が 少ないので Fig. 4 から除外した. 合計 36匹吸血し22匹 がRケージで回収された), それに $1.28 \mathrm{~g}$ 以上でのヒト スジシマカが高率にRケージで回收された．フェニトロ チオンでは An. stephensi と $0.04 \mathrm{~g} / \mathrm{m}^{2}$ よりも施用 量が多い場合のヒトスジシマカに， Rケージ逃避が認め
られた。

\section{実 験 2}

実験 1 と同条件だが，蚊はB ケージのマウスのそばに 放った，吸血のためには網を通りぬける必要がないか ら，Rケージに放した場合よりも吸血率, 致死率ともに 薬㶡の影響が少ないという想定であった。しかし Table 3 に示すようにフェノトリン処理の場合には，3種の供 試蚊いずれも，どの濃度でも実験 1 に比べて高い致死率 となった，吸血率（Fig. 5) は少し高率かまたはほぼ同 率で，いずれも有意な差はない．網通過の必要がないの に無処理区ほどの高吸血率にはならなかった。フェニト ロチオン処理では，致死率は実験 1 と大差なかったが， 吸血率はどの蚊も高率となった。

吸血後 Rケージへ逃避した蚊の比率は，やはり実験 1 と同じょうな傾向であった. 各濃度での吸血蚊を合計し てその比率は, フェノトリンでは An. stephensi 68.8 \% (実験 1 では $70 \%$ )，ヒトスジシマカ $20.2 \%$ (17.7 \%), アカイエカ $45.4 \%$ (43.4\%). フェニトロチオン では同じく $59.5 \%$ (73.7\%), 36.1\% (36.9\%), 59.7 \% (55.5\%) であった.

Fig. 5 にみるように，Bケージに放したのにかかわ らず多数の未吸血蚊がRケージで回収された．フェノト 

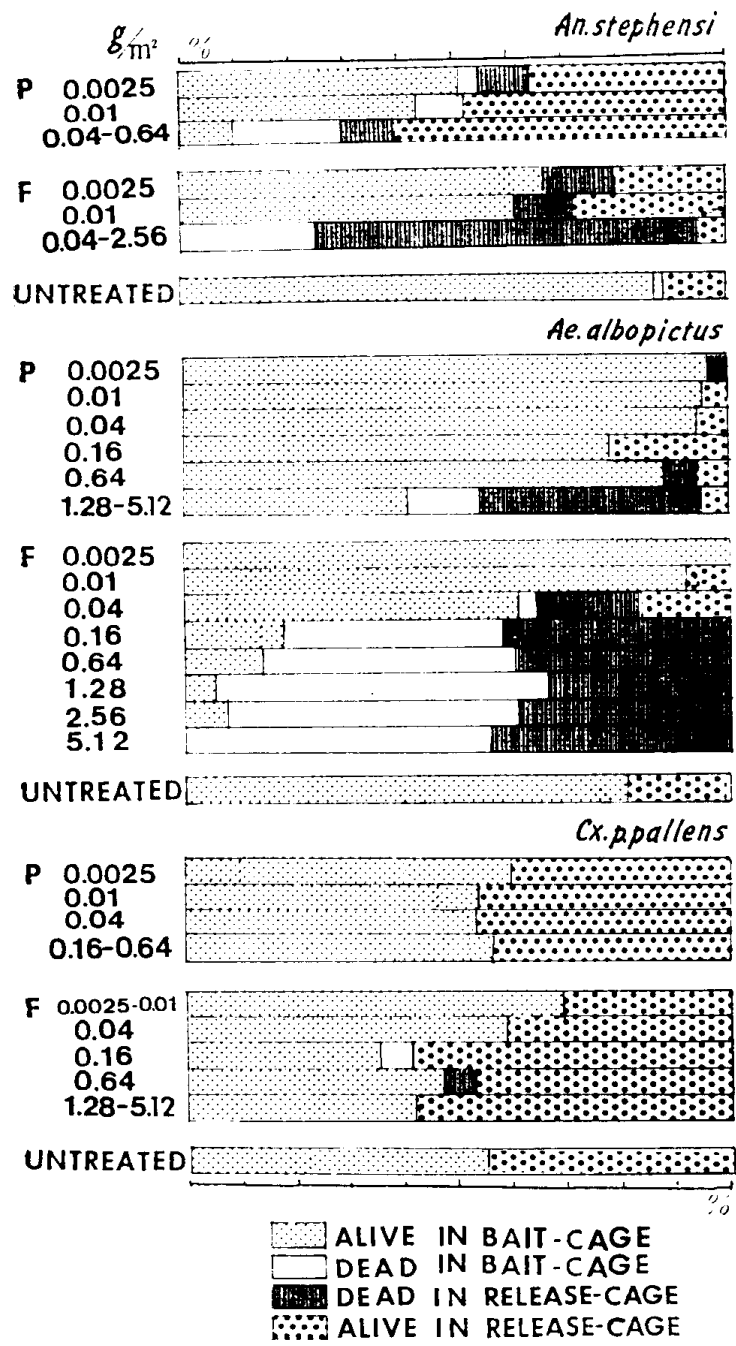

Fig. 4 Responses to insecticides in terms of resting place after blood-feeding. " $P$ " and " $F$ " denote phenothrin and fenitrothion, respectively.

Table 3 Over-all mortalities (\%) of mosquitoes in two cages.

\begin{tabular}{lcccc}
\hline \hline Insecticide & $\begin{array}{c}\text { Dosage } \\
\left(\mathrm{g} / \mathrm{m}^{2}\right)\end{array}$ & $\begin{array}{c}\text { An. } \\
\text { stephensi }\end{array}$ & $\begin{array}{c}\text { Ae. } \\
\text { albopictus }\end{array}$ & $\begin{array}{c}\text { Cx.p. } \\
\text { pallens }\end{array}$ \\
\hline Phenothrin & 0.04 & 56.9 & 28.8 & - \\
& 0.16 & 80.5 & 39.7 & 19.2 \\
& 0.64 & 84.7 & 49.0 & 32.0 \\
Fenitrothion & 1.28 & 87.6 & 75.9 & 68.0 \\
& 0.04 & 84.6 & 35.2 & - \\
& 0.16 & 100 & 58.4 & 16.6 \\
& 0.64 & 100 & 84.6 & 15.6 \\
Untreated & 1.28 & 98.8 & 90.0 & 16.9 \\
& & 8.9 & 13.2 & 6.2 \\
\hline
\end{tabular}

The insecticide impregnated net was interposed between two cages, and the mosquitoes were introduced into the bait-cage.
リンではとくにその比率が高くAn. stephensi で注供試 蚊の 70 80\%，ヒトスジシマカは $25 \sim 47 \%$ ，アカイエ カ 18 50\%におよんだ.この值は， Rケージに放して B ケージに侵入を避けた比率に匹敵する。フェニトロチ オンでは，An. stephensi が高率であった。なお $\mathrm{R}$ ケー ジ回收蚁の致死率は，アカイエカ以外で流、。

\section{考察}

壁面などに散布された殺虫剤に反応して蚊成虫が，国 有の行動的特徴を変える事例は, Elliott and Zulueta （1975）が多数の文献を総説したが，これらの多くは， 反応が DDT の殺虫効果を損わないかと危惧された （WHO，1960）ための研究だった. しかし，いわ河る 抵抗性ほどには注目されることもなかったようだ。近年 人畜への低毒性で期待されるピレスロイドに対し，蚊 が似たような現象を示すことが野外試験で報告され (Smith and Chabeda, 1969 ; Coosemans and Sales, 1977 ; Rishikesh ら，1978)，再度関心を深的ざるをえ なくなった.

その現象は，次の 4 点に要約される. (1) 散布した家 屋内に入ってこない，(2) 入ってきても吸血しない，(3) 吸血をしてもすぐ外一飛び出してしまう．(4)入ってき ても吸血しないで外一出る.これらの行動をとる蚊の比 率が高くなるというわけである。しかしこのような侵入 や吸血をためらったり外一逃げ出すというのは，ためら いをみせなかった多くの蚊が薬剤に触れて死んだため に，高い比率となり注目されたのか，あるいは薬剤に反 応して可逆的な行動をとった個体なのかという疑問を残 す。もし後者ならば，その薬剤は疫学的に有効に作用し ているのか否か, 検討を要する.

そこでこれらの行動を室内試験で具現させて検討して みた. 従来も DDT を対象に, Kennedy (1947), Gerold and Laarman (1964), Brown (1964) などが試み ているが，いずれも紙などに塗った殺虫剤を供したもの で，irritabilityを調べることに重点がおかれていた．侵 入減少などの効力を検討した Gheorghiu ら（1972）の 装置は，大型の木箱によるものだが，これは野外飛来蚊 を対象としたものであった。

今回のケージテストは，蚊の通り欢汁が可能な網とい う素材，そして異なる多段階の薬剤施用量で比較すると いう手法により, 蚊が薬剤のバリヤーを避ける比率や吸 血をためらう率を算出し，さらにその值が薬凬や供試蚊 種により大小異なり比皎をすることが可能となった。

すなわち，フェノトリンが起こさせた，上述の(1)〜(4) に相当する反応は，次のように見いだすことができた。

(1) Bケージへの侵入阻害 deterrent effect : 0.04 


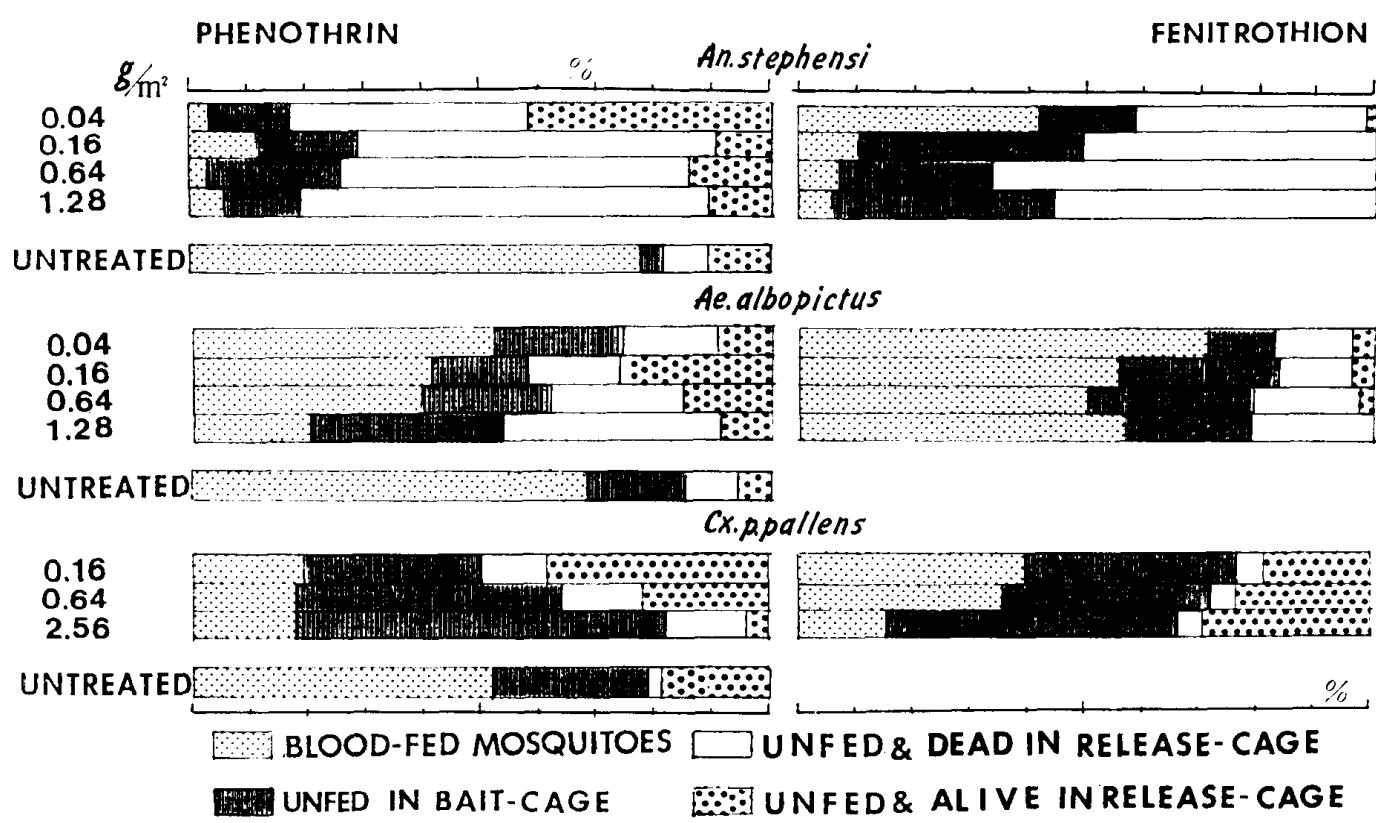

Fig. 5 Responses to insecticides in terms of feeding and exit of mosquitoes which were introduced into the bait-cage.

$0.64 \mathrm{~g} / \mathrm{m}^{2}$ 処理の網では, 蚊が薬剤に阻害されて侵入で きず， R ケージに残留する比率が増加した。これより高 濃度では，この行動が網接触一致死となり隠されてしま うし，無処理と同程度のRケージ残留末吸血蚊が生存し てはいるが，これは網に接近しない，吸血意欲を欠く個 体だろう。しかしなかには，アカイエカのように残留生 存蚊の比率が増加しない種もあった。この場合の侵入率 低下は致死率が高まったためである。

(2) 吸血阻害 feeding deterrency : 吸血率低下に加え て，侵入しながら吸血をしない生存蚊の比率により評価 しうる. $0.04 \sim 0.64 \mathrm{~g}$ 処理で 3 種の蚊に吸血阻害・忌 避と，吸血率低減をみた。ヒトスジシマカだけは吸血率 低下の原因は，吸血をためらったためではなく致死率増 加によるところが大きい，本種の侵入蚊吸血比率は，網 に触れられなくても（栗原・海野，1986）また，Bケージ に放しても，処理網の存在には無関係で，よく吸血する.

(3) 吸血後の逃避 irritant effect：無処理網使用 さいの成績との対比で反応を評価しうる. 吸血後 Rケー ジへ逃避した比率は An. stephensi とネッタイイエカ で高く，アカイエカでは顕著ではない，ヒトスジシマカ は高濃度に限って見られた。

(4) 未吸血での逃避 : ゴキブリ等でいわれている flushing outに相当しよう。蚊がバリヤーを越して侵入し た後，未吸血のまま $\mathrm{R} に$ 戻るか否かは証明できなかっ た.しかしBケージに放したのにとくに An. stephensi は, 未吸血でRケージに启ることが多いのが注目される.

以上に対してフェニトロチン処理網に対しての反応・ 可逆的な行動は，目立たない。狭いケージ内で Air- borne (Fontaine et al., 1975) の致死作用が, 侵入や吸 血以前に強く作用したことにもよる. 網に触れる必要の ないBケージに放した場合, どの濃度でも高い吸血率と なったが，吸血後の致死率も高い.このように侵入や吸 血を忌避し生存する現象は少ない，ただ本薬剤に抵抗性 のアカイエカは, 当然低致死率だが, 吸血を避ける行動 を示した、Bケージに放した場合も，生存末吸血蚊が多 W.

吸血後あるいは未吸血での逃避は，An. stephensi で は顕著であった。

反応のあらわれ方が，蚊種により異なったが，それが 何に由来するかは興味がある.DDT による侵入阻害や 吸血後の逃避は, An. gambiae には強く, ネッタイイ エカには弱くしか作用しなかった (Zulueta and Cullen, 1963; Smith and Webley, 1969) という. 今回のフェ ノトリンに対しては, An. stephensi は最も敏感に反応 し，(1)〜 (4)の行動を示した. 逆に大きい LT50 值をも つアカイエカは，侵入蚊の吸血阻害以外は，あまり明確 に反応しなかった. それと同じイエカ属のネッタイイエ カは, An. stephensi と同様によく反応した.こうして みると, 感受性が高いとより鋭敏に反応を示すといえそ うだ.しかし，一方でヒトスジシマカのみが吸血阻害を 示さないこと，またアカイエカのみがフェニトロチオン で吸血阻害を示したことから，種による特異性も無視は できない，抵抗性との関係において，この問題は早期に 検討解決を図りたい.

フェノトリンの場合は，ケージテストでは蚊が網に接 近するのをためらうためか，100％致死には至らなかっ 
た.しかし $0.64 \mathrm{~g} / \mathrm{m}^{2}$ 以上の施用では，侵入と吸血をフ エニトロチオンより強く抑制した．しかも，本薬剤は蒸 気圧が低い（伊藤高明博士私信）のにかかわらず，An. stephensi の侵入吸血を，処理網に触れないようにし ても抑制する (栗原・海野，1986). 他のピレスロイド, ペルメスリン処理の衣服を着ていると, 露出している顔 を刺しにくる蚊が激減した (Lindsay and Mcandles, 1978）といら報告もあるから,フェノトリンの新しい用途 としても注目される. マラリア対策の focal spray など に供すると，家屋内居住者の吸血防止に効果を示寸もの と期待される.

$$
\text { まとめ }
$$

ピレスロイドを壁面噴霧した場合，雌蚊成虫はこれに 反応して多様な行動をとることが予想される.これらの 行動の度合を実験室内で検討することを目的として，簡 易な試験装置を作った：三つの $30 \mathrm{~cm}$ 角ケージの一方 に固定したマウス，他方に吸血意欲の強い雌蚊を放つ. ケージは口径 $15 \mathrm{~cm}$ の開孔部をあい接し，その接面に は, 様々な濃度の殺虫㓮を浸漬した, 目の大きさ $1 \mathrm{~cm}$ 角のナイロン網をはる。较は放して翌朝回収した。

供試した薬剤のうちフェノトリンは，An. stephensi に対して低濃度で侵入をためらわせ，侵入しても吸血を 避け，さらに吸血してもすぐ逃避してしまう反応を起こ させた.これらの反応は $0.64 \mathrm{~g} / \mathrm{m}^{2}$ 以上では高致死率に マスクされ明確には表現されない.蚊をべイト・ケージに 放って，末吸血のまま逃避するフラッシング効果も観察 された.このような反応は, 蚊種により表現が異なり, たとえば，アカイエカの侵入率とヒトスジシマカの吸血 率は, フェノトリンによる高い致死率のために漸減して しまったが，侵入や吸血を避仙ようといら行動のためで はないと判断しえた。

フェニトロチオン処理網を用いると, 侵入吸血が低減 したが，これも強い致死作用によるものだった。ただア カイエカには, 強い抵抗性を示すにかかわらず, 吸血を 阻害させる効力を示した。

殺虫刜が及ぼす蚊の行動への影響を，飼育蚊を供して 簡易にバイオアッセイし，その反応の度合を比較するこ とが，可能であった。

住友化学工業 (株) 宝塚研究所新庄五朗博士, 伊藤禀 明博士には，文献のご教示をいただいた。

\section{引用文献}

Brown, A. W. A. (1974): Experimental observations governing the choice of a test method for determining the DDT-irritability of adult mosquitos. Bull. W. H. O., 30 : 97-111.
Coosemans, M. H. and S. Sales (1977): Stage IV evaluation of five insecticides-OMS 43, OMS 1810, OMS 1821, OMS 1825 and OMS 1998-against Anopheline mosquitoes at the Soumousso experimental station, Bobo Dioulasso, Upper Volta. WHO/VBC/77, 663.

Elliott, R. and J. de Zulueta (1975) : Ethological resistance in malaria vectors. Behavioural response to intradomestic residual insecticides. $W H O / V B C / 75,569$.

Fontaine, R. E., G. P. Joshi and G. D. Pradhan (1975): Entomological evaluation of fenitrothion as a residual spray for the control of An. gambiae and An. funestus, Kisumu, Kenya. $W H O / V B C / 75,547$.

Gerold, J. L. and J. J. Laarman (1964): Selection of some strains of Anopheles artoparvus with different behavioural responses to contacts with DDT. Nature, 204 : 500-501.

Gheorghiu, T., E. M. Ungureanu and C. Garrett-Jones (1972): An apparatus for the study of the behaviour patterns of mosquitos under the influence of insecticides. Bull. W. H. O., 46 : 122-126.

Kennedy, J. S. (1947): The excitant and repellent effects on mosquitos of sub-lethal contacts with DDT. Bull. Entomol. Res., 37 : 593-607.

梠原 毅, 藤田和世, 鈴木 猛 (1985a)：蚊成出の 殺虫剂処理網に対する接触試験と殺虫剤に対する 反応. 衛生動物, 36:25-30.

栗原 毅, 海野登久子, 上村 清, 荒川 良 (1985 b): 殺虫剂処理網に対する蚊成虫の反匛之豚全での防 蚊試験. 衛生動物, $36: 148$.

栗原 毅，海野登久子 (1986)：殺虫剂処理網に対 する蚊成出の反応室内試験。衛生動物, $37: 176$.

Kurihara, T., K. Kamimura and R. Arakawa (1986): Phenothrin impregnation of widemesh net for protection from biting mosquitoes. Jpn. J. Sanit. Zool., $37: 261-262$.

Lindsay, I. S., and J. M. Mcandless (1978 : Permethrin-treated jackets versus repellenttreated jackets and hoods for personal protection against black flies and mosquitoes. Mosq. News, 38 : 350-356.

Mattingly, P. F. (1962): Mosquito behaviour in relation to disease eradication programmes. Annu. Rev. Entomol., $7:$ 419-436.

Muirhead-Thomson, R. C.(1960) : The significance of irritability, behaviouristic avoidance and allied phenomena in malaria eradication. Bull. W. H. O., 22 : 721-734.

Rishikesh, N., J. L. Clarke, H. L. Mathis, J. S. King and J. Pearson (1978): Evaluation of decamethrin and permethrin against Anopheles gambiae and Anopheles funestus in a village trial in Nigeria. $W H O / V B C / 78,689$. 
Smith, A. and P. I. M. Chabeda (1969): A verandah-trap hut for studying the housefrequenting habits of mosquitos and for assessing insecticides. The effects of phthalthrin on the behaviour and mortality of Anopheles gambiae Giles. WHO/MAL/69, 699.

Smith, A. and D. J. Webley (1969): A verandah-trap hut for studying the house-frequenting habits of mosquitoes and for assessing insecticides. III. The effect of DDT on behaviour and mortality. Bull. Entomol. Res., 59 : 33-46.

WHO (1960): Insecticide resistance and vector control. W. H. O. Tech. Rep. Ser., 191 : 98.

Zulueta, J. de. and J. R. Cullen (1963): Deterrent effect of insecticides on malaria vectors. Nature, 200 : 860-861.

\section{Summary}

In order to study the effects of insecticides on the behaviour of female mosquitoes under the laboratory conditions, a series of cage tests were carried out. The apparatus was composed of two wire-cages $(30 \times 30 \times 30 \mathrm{~cm}$ each $)$; one served as a release cage of avid mosquitoes and the other served as a mouse-baited cage. The wide-mesh net was impregnated with the candidate insecti- cide at different doses and interposed between the two cages, but the mosquitoes were able to pass through the mesh. The mosquitoes were introduced at $3 \mathrm{pm}$ and recovered $19 \mathrm{hrs}$ later. The result showed that phenothrin treated net had marked effects on the behaviour of Anopheles stephensi. There was a high level of inhibition in entering the bait-cage and in feeding blood. Also fed mosquitoes were driven out of the baitcage by the irritant action of the insecticide. However, a high mortality masked those responses at a dose higher than $0.64 \mathrm{~g} / \mathrm{m}^{2}$. It was also demonstrated that the avid mosquitoes, which were introduced into the bait-cage, moved away to the other cage without feeding. In the case of Culex pipiens pallens, deterrent effects in the entering behaviour were almost negligible. Feeding in Aedes albopictus was less inhibited than in the other mosquitoes. Reduction of entry and feeding by the fenitrothion treated net was due to high mortality of mosquitoes. The inhibition of feeding was observed in $C x$. pipiens pallens which shows high resistance to this insecticide, though they entered the bait-cage. This apparatus seems to be practical for assessing the behavioural reaction to insecticides of various species of mosquitoes. 